\title{
PMS2 gene mutation results in DNA mismatch repair system failure in a case of adult granulosa cell tumor
}

\author{
Wen-Chung Wang ${ }^{1}$, Ya-Ting Lee ${ }^{2}$ and Yen-Chein Lai ${ }^{*}$
}

\begin{abstract}
Background: Granulosa cell tumors are rare ovarian malignancies. Their characteristics include unpredictable indolent growth with malignant potential and late recurrence. Approximately $95 \%$ are of adult type. Recent molecular studies have characterized the FOXL2 402C > G mutation in adult granulosa cell tumor. Our previous case report showed that unique FOXL2 402C > G mutation and defective DNA mismatch repair system are associated with the development of adult granulosa cell tumor.

Findings: In this study, the DNA sequences of four genes, MSH2, MLH1, MSH6, and PMS2, in the DNA mismatch repair system were determined via direct sequencing to elucidate the exact mechanism for the development of this granulosa cell tumor. The results showed that two missense germline mutations, T485K and N775L, inactivate the PMS2 gene.

Conclusions: The results of this case study indicated that although FOXL2 402C > G mutation determines the development of granulosa cell tumor, PMS2 mutation may be the initial driver of carcinogenesis.

Immunohistochemistry-based tumor testing for mismatch repair gene expression may be necessary for granulosa cell tumors to determine their malignant potential or if they are part of Lynch syndrome.
\end{abstract}

Keywords: Granulosa cell tumor, DNA mismatch repair system, Direct sequencing

\section{Findings}

\section{Introduction}

There are three main types of ovarian cancer: sex cordstromal, epithelial, and germ cell [1]. Sex cord-stromal tumors develop from gonadal stromal component and represent about $8 \%$ of all ovarian tumors [2]. Among them, $70 \%$ are granulosa cell tumors [3], characterized by indolent growth with malignant potential [4] and late recurrence, even after more than a decade [5]. There are two distinct forms of granulosa cell tumor, adult and juvenile, based primarily on clinical presentations and histopathologic characteristics [6]. The adult form comprises about $95 \%$ of granulosa cell tumors and frequently presents in postmenopausal women with uterine bleeding [7]. The juvenile form is much more rare,

\footnotetext{
* Correspondence: yenchein@csmu.edu.tw

${ }^{2}$ Department of Medical Laboratory and Biotechnology, Chung Shan Medical University, No.110, Sec. 1, Chien Kuo N. Road, Taichung 402, Taiwan, Republic of China

Full list of author information is available at the end of the article
}

comprising only about $5 \%$ of granulosa cell tumors, and affects young women in their first 3 decades of life [7]. Recent studies have revealed that FOXL2 gene 402C > G (C134W) mutation plays a key role in the pathogenesis of adult granulosa cell tumor $[5,8]$.

In our previous study [9], we reported an 80-year-old woman with a granulosa cell tumor arising from the ovary. Molecular studies showed a heterozygous FOXL2 $402 \mathrm{C}>\mathrm{G}$ mutation in the tumor on direct gene sequencing. DNA replication error was demonstrated on analysis of the lengths of CAG repeats in androgen receptor gene, in addition to defective DNA mismatch repair system. DNA mismatch repair system failure appeared likely in this patient via genomic imbalances determined on array comparative genomic hybridization analysis. In this study, the DNA sequences of four genes, MSH2, MLH1, MSH6, and PMS2, in the DNA mismatch repair system were determined via direct sequencing to elucidate the exact mechanism for the development of this granulosa cell tumor. 


\section{Materials and methods Isolation of DNA}

Genomic DNA was isolated from peripheral blood lymphocytes using the QIAamp DNA blood kit (QIAGEN $\mathrm{GmbH}$, Hilden, Germany). Somatic DNA was prepared from sections of paraffin embedded tissue using the QIAamp tissue kit (QIAGEN). DNA was finally dissolved in $100 \mu \mathrm{l}$ of TE buffer $(10 \mathrm{mM}$ Tris- $\mathrm{HCl}, \mathrm{pH}$ 8.0, and $1 \mathrm{mM}$ EDTA). Concentrations of the DNA stocks were estimated by spectrophotometer. Each genomic DNA sample was adjusted to $100 \mathrm{ng} / \mu \mathrm{l}$ to serve as a template for subsequent analyses.

\section{Polymerase chain reaction}

The exons of four genes, MSH2, MLH1, MSH6, and $P M S 2$, were amplified in fragments using published primers from Sequenom ${ }^{\circ}$ Standard EpiPanel. The PCR fragments were amplified in a Perkin-Elmer 2400 DNA thermal cycler in a final volume of $30 \mu \mathrm{l}$ containing onefold Qiagen PCR buffer [Tris- $\mathrm{HCl}, \mathrm{KCl},\left(\mathrm{NH}_{4}\right)_{2} \mathrm{SO}_{4}$, $15 \mathrm{mM} \mathrm{MgCl}$; $\mathrm{pH} 8.7$ at $20{ }^{\circ} \mathrm{C}$ ], one-fold Q-solution, 0.015 units/ $\mu \mathrm{l}$ Taq DNA polymerase from Taq DNA polymerase kit (Qiagen), $500 \mathrm{nM}$ for each primer, $200 \mu \mathrm{M}$ dGTP, dATP, dCTP and dTTP (Promega; Madison, WI, USA) and $300 \mathrm{ng} / \mu \mathrm{l}$ template. The PCR conditions were initial denaturation at $95{ }^{\circ} \mathrm{C}$ for $5 \mathrm{~min}$, followed by 35 cycles at $95{ }^{\circ} \mathrm{C}$ for $1 \mathrm{~min}$, at annealing temperature for $1 \mathrm{~min}$, and at $72{ }^{\circ} \mathrm{C}$ for $2 \mathrm{~min}$, with final extension at $72{ }^{\circ} \mathrm{C}$ for $10 \mathrm{~min}$.

\section{Direct sequencing}

PCR products were purified using QIA quick PCR Purification kits (Qiagen GmbH., Hilden, Germany). The purified PCR products were sequenced using the cyclesequencing method with fluorescently labeled dideoxy chain terminators from ABI Prism kit (Applied Biosystems, Taipei, Taiwan) in an ABI Prism 3100 automated DNA sequencer, according to the distributor's protocol. The sequencing primers were the same as those for the preceding PCRs. When a mutation was detected, the nucleotide sequence was confirmed on both strands.

\section{Results}

The DNA sequences of four genes, MSH2, MLH1, MSH6, and PMS2, in the DNA mismatch repair system were determined via direct sequencing. We found five point mutations in the exon region of PMS2 gene in the DNA samples from paraffin-embedded tumor specimens (Table 1). Among them, there were two missense mutations. Threonine was nonconservatively substituted to lysine via heterozygous mutation at codon 485 in exon 11 (T485K), 26796C > A (Fig. 1a) and asparagine was nonconservatively substituted to leucine via heterozygous mutation at codon 775 (N775L) in exon
Table 1 Nucleotide alterations in the exon regions of PMS2 gene in the DNA mismatch repair system in granulosa cell tumor

\begin{tabular}{llllll}
\hline Nucleotide & Alteration & Exon & Codon & Amino Acid & Zygote \\
\hline 10352 & C $>$ T & 4 & 96 & Ala & Heterozygote \\
16758 & C $>$ G & 7 & 280 & Ser & Homozygote \\
26796 & C $>$ A & 11 & 485 & Thr $>$ Lys & Heterozygote \\
36398 & A $>$ G & 14 & 775 & Asn $>$ Leu & Heterozygote \\
40585 & T $>$ G & 15 & 822 & Leu & Heterozygote \\
\hline
\end{tabular}

GenBank accession number NG_008466.1 for nucleotide and NP_000526 for amino acid

14, 36398A > G (Fig. 1c). These two heterozygous loci were also identified in lymphocytic DNA (Fig. 1b and d). There were three silent mutations, with no change in amino acid sequence. The mutations at codon 96 in exon 4, 10352C $>\mathrm{T}$ and codon 822 in exon 15, $40585 \mathrm{~T}>\mathrm{G}$ were heterozygous. A homozygous mutation was found at codon 280 in exon 7, 16758C > G.

The DNA samples from paraffin-embedded tumor specimens were negative for somatic mutations in the exon regions of the other three genes, MSH2, MLH1, and MSH6. There were nucleotide alterations in the intron regions in almost all mismatch repair genes (Table 2). However, splicing status was not affected. These passenger mutations may be attributed to clonal evolution during tumorigenesis.

\section{Discussion}

Forkhead box protein L2 is encoded by FOXL2 gene. Many functions of this protein are associated with the features of granulosa cell tumor [8], including estrogen receptor binding activity, positive regulation of luteinizing hormone and follicle-stimulating hormone secretion, positive regulation of apoptotic process and granulosa cell differentiation [10]. When mutated, granulosa cells may be affected and tumor may grow without apoptosis. By itself, this cannot explain why granulosa cell tumor has malignant potential. PMS2, a gene responsible for Lynch syndrome, previously referred to as hereditary nonpolyposis colorectal cancer, was mutated in this case of granulosa cell tumor. Although granulosa cell tumor is not a pathognomonic malignancy of Lynch syndrome, it has been found in 2/74 ovarian cancers in Lynch syndrome family [11]. Therefore, a reasonable explanation for our findings is that PSM2 mutation precedes FOXL2. This indicates that late malignancy may be due to PSM2 and not FOXL2 itself. Immunohistochemical study may be needed for granulosa cell tumors to exclude Lynch syndrome.

The MutL $\alpha$ heterodimer formed by mismatch repair proteins MLH1 and PMS2 is a major component of the mismatch repair complex, yet mutations in the PMS2 gene are rare in the etiology of Lynch syndrome [12]. 


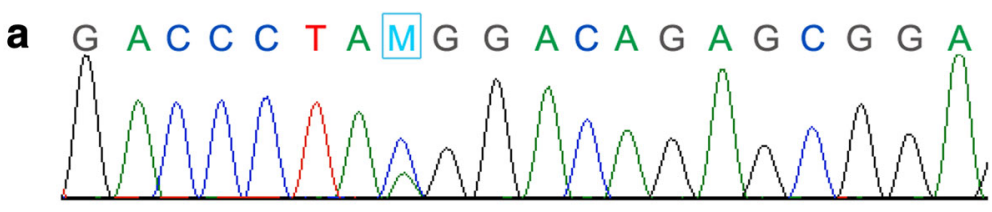

b $G A C C C T A M G G A C A G A G C G G A$

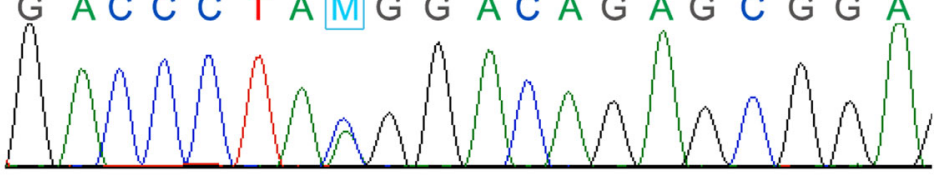

c $C$ T A G T A A A A R

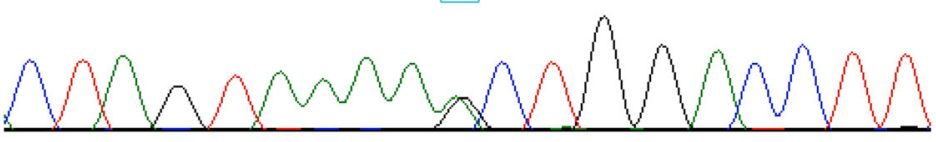

d $C$ T A

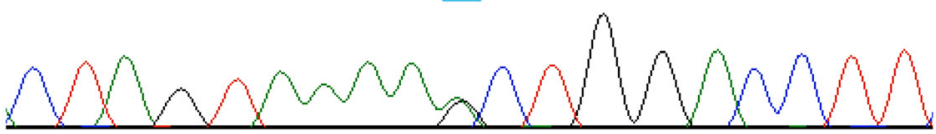

Fig. 1 Partial sequencing chromatograms present the heterozygous T485K (26796 C > A, A, B) and N775L (36398 A > G, C, D) mutations in the PMS2 gene. Nucleotide sequences were determined from granulosa cell tumor $(\mathbf{a}, \mathbf{c})$ and normal sample (peripheral blood lymphocytes, $\mathbf{b}$, $\mathbf{d}$ ). Blue triangles indicate the positions of nucleotide numbers $26796(\mathrm{M}=\mathrm{A} C)$ and $36398(\mathrm{R}=\mathrm{G}$ A)

The missense variant $\mathrm{N} 775 \mathrm{~L}$, which is located in the MLH1 protein-interacting region, has not been previously reported. The nonconservative substitution of asparagine to leucine might change the $N$-glycosylation status of PMS2 protein. A previous study has illustrated $N$-glycosylation changes in colorectal cancer tissues when compared with accompanying control tissues [13].
The missense variant $\mathrm{T} 485 \mathrm{~K}$ is a rare polymorphism in the general population [14].

Although granulosa cell tumors are very rare, their potential for malignancy makes them clinically significant and it is important to identify the molecular mechanisms involved in their development [4]. A single genetic lesion is rarely sufficient to promote tumorigenesis, but it does

Table 2 Nucleotide alterations in the intron regions of four genes in the DNA mismatch repair system in granulosa cell tumor

\begin{tabular}{|c|c|c|c|c|c|}
\hline Gene & Nucleotide & Alteration & Zygote & Intron & GenBank \\
\hline$\overline{M L H 1}$ & 37259 & 1 base $(A)$ deletion & Heterozygote & 12 & NG_007109.2 \\
\hline MLH1 & 59246 & $C>G$ & Heterozygote & 14 & NG_007109.2 \\
\hline MSH2 & 10262 & 1 base $(A)$ deletion & Heterozygote & 1 & NG_007110.2 \\
\hline MSH2 & 16320 & 4 bases (AAAA) deletion & Heterozygote & 4 & NG_007110.2 \\
\hline $\mathrm{MSH} 2$ & 65062 & 2 bases $(A A)$ insertion & Homozygote & 9 & NG_007110.2 \\
\hline MSH2 & 68697 & $G>A$ & Heterozygote & 10 & NG_007110.2 \\
\hline $\mathrm{MSH} 2$ & 78202 & 1 base $(\mathrm{A})$ deletion & Homozygote & 12 & NG_007110.2 \\
\hline MSH2 & 78234 & $\mathrm{~T}>\mathrm{C}$ & Heterozygote & 12 & NG_007110.2 \\
\hline MSH6 & 5480 & $G>A$ & Heterozygote & 1 & NG_007111.1 \\
\hline MSH6 & 25553 & $A>T$ & Homozygote & 5 & NG_007111.1 \\
\hline MSH6 & 27596 & 4 bases (ATCT) deletion & Homozygote & 7 & NG_007111.1 \\
\hline MSH6 & 28266 & $C>G$ & Homozygote & 8 & NG_007111.1 \\
\hline PMS2 & 15016 & $A>G$ & Heterozygote & 6 & NG_008466.1 \\
\hline PMS2 & 31112 & $G>A$ & Heterozygote & 11 & NG_008466.1 \\
\hline PMS2 & 31334 & $A>G$ & Heterozygote & 12 & NG_008466.1 \\
\hline PMS2 & 35294 & $\mathrm{~T}>\mathrm{C}$ & Heterozygote & 12 & NG_008466.1 \\
\hline
\end{tabular}


create a mutator phenotype which predisposes to additional mutations involved in cancer development. The PMS2 N775L mutation was identified in both lymphocyte and tumor in this study. The FOXL2 402C > G mutation was observed in granulosa cell tumor, but not in the blood or normal tissue [9]. Therefore, the tumor exhibited both PMS2 and FOXL2 mutations, and PMS2 mutation occurred before FOXl2 mutation. The results of this study indicated that the amino acid changing mutation, N775L, in PMS2 gene may be the driver mutation which induces DNA mismatch repair system failure. Our hypothesis is that DNA mismatch repair system failure induces FOXL2 $402 \mathrm{C}>\mathrm{G}$ mutation, leading to granulosa cell tumor development [9]. The DNA mismatch repair system failure randomly causes further mutations of tumor suppressor genes or oncogenes, resulting in late recurrence and unpredictable malignant behavior of granulosa cell tumor [9].

The tumor spectrum in Lynch syndrome is associated with germline mutations of DNA mismatch repair genes involving 8 or more organ sites, such as colorectal, endometrial and ovarian cancers [15]. Adrenal and gonadal steroidogenic cells share a common developmental origin, adreno-genital primordium [16]. The development of granulosa cell tumor may be similar to that of adrenocortical carcinoma, a malignancy of steroidogenic cells, which has been demonstrated to be associated with Lynch syndrome [17]. We may add this special type of ovarian tumor to Lynch syndrome, which may allow for early detection and treatment. Immunohistochemistrybased tumor testing for mismatch repair gene expression may be necessary for granulosa cell tumor to determine malignant potential or if part of Lynch syndrome [18]. This would provide accurate prognosis and prophylactic information for patients with this type of tumor.

Although direct sequencing of affected genes is definitive and identifies the specific mutation in a family, mutations involving exon skipping or located outside the amplified fragment may be missed on DNA-based screening [14]. Moreover, granulosa cell tumors are rare. It is necessary to test more granulosa cell tumor patients for Lynch syndrome to evaluate the prevalence and association of granulosa cell tumor and Lynch syndrome in the future. A single case may not be adequate to determine the exact cause of this type of tumor. More case reports are required to understand the molecular characteristics of these tumors, other than the FOXL2 gene, and elucidate their connections with mismatch repair system.

\section{Conclusions}

The results of this case study indicated that although FOXL2 402C > G mutation determines the development of granulosa cell tumor, PMS2 N775L mutation may be the initial driver of carcinogenesis. Early detection may allow for better treatment of granulosa cell tumor. Immunohistochemistry-based tumor testing for mismatch repair gene expression may be necessary for granulosa cell tumor for determining malignant potential or if part of Lynch syndrome.

\section{Abbreviations \\ DNA: Deoxyribonucleic acid; FOXL2: Forkhead box protein L2; MLH1: MutL homolog 1; MSH2: MutS homolog 2; MSH6: MutS homolog 6; PCR: Polymerase chain reaction; PMS2: PMS1 homolog 2}

\section{Acknowledgments}

The authors would like to express their thanks for the technical support provided during the acquisition of direct sequencing data by the Sofiva Genomics Laboratory of Dianthus Maternal Fetal Medicine Clinic

(Taipei, Taiwan), under the direction of Dr Yi-Ning Su.

\section{Funding}

Not applicable.

\section{Availability of data and materials}

The data that support the findings of this study are included within the article and its additional files. The datasets analysed during the current study are available from the corresponding author.

\section{Authors' contributions}

YCL designed the experiments, performed the experiments, interpreted the results, and drafted the manuscript. YTL participated in experiments and analysis of results. WWC designed the experiments, provided samples and clinical data, interpreted the results and made critical revisions to the manuscript. All authors have read and approved the final manuscript.

\section{Competing interests}

The authors declare that they have no competing interests.

\section{Consent for publication}

Not applicable.

Ethics approval and consent to participate

This study was approved by the Institutional Review Board of Chung Shan Medical University Hospital, reference number CS2-16082.

\section{Publisher's Note}

Springer Nature remains neutral with regard to jurisdictional claims in published maps and institutional affiliations.

\section{Author details}

'Department of Obstetrics and Gynecology, Jen-Ai Hospital, Taichung, Taiwan. ${ }^{2}$ Department of Medical Laboratory and Biotechnology, Chung Shan Medical University, No.110, Sec. 1, Chien Kuo N. Road, Taichung 402, Taiwan, Republic of China.

Received: 6 January 2017 Accepted: 22 March 2017

Published online: 27 March 2017

\section{References}

1. Scully RE. Classification of human ovarian tumors. Environ Health Perspect. 1987:73:15-25.

2. Outwater EK, Wagner BJ, Mannion C, McLarney JK, Kim B. Sex cord-stromal and steroid cell tumors of the ovary. Radiographics. 1998;18:1523-46.

3. Schumer ST, Cannistra SA. Granulosa cell tumor of the ovary. J Clin Oncol. 2003;21:1180-9.

4. Geetha P, Nair MK. Granulosa cell tumours of the ovary. Aust N Z J Obstet Gynaecol. 2010;50:216-20.

5. Mancari R, Portuesi R, Colombo N. Adult granulosa cell tumours of the ovary. Curr Opin Oncol. 2014;26:536-41.

6. Jamieson S, Fuller PJ. Molecular pathogenesis of granulosa cell tumors of the ovary. Endocr Rev. 2012;33:109-44. 
7. Kavuri S, Kulkarni R, Reid-Nicholson M. Granulosa cell tumor of the ovary: cytologic findings. Acta Cytol. 2010;54:551-9.

8. Shah SP, Kobel M, Senz J, Morin RD, Clarke BA, Wiegand KC, et al. Mutation of FOXL2 in granulosa-cell tumors of the ovary. N Engl J Med. 2009:360:2719-29.

9. Wang WC, Lai YC. Molecular pathogenesis in granulosa cell tumor is not only due to somatic FOXL2 mutation. J Ovarian Res. 2014;7:88.

10. Georges A, Auguste A, Bessiere L, Vanet A, Todeschini AL, Veitia RA. FOXL2: a central transcription factor of the ovary. J Mol Endocrinol. 2014;52:R17-33.

11. Nakamura K, Banno K, Yanokura M, lida M, Adachi M, Masuda K, et al. Features of ovarian cancer in Lynch syndrome (review). Mol Clin Oncol. 2014;2:909-16

12. Nakagawa H, Lockman JC, Frankel WL, Hampel H, Steenblock K, Burgart L, et al. Mismatch repair gene PMS2: disease-causing germline mutations are frequent in patients whose tumors stain negative for PMS2 protein, but paralogous genes obscure mutation detection and interpretation. Cancer Res. 2004:64:4721-7.

13. Balog Cl, Stavenhagen K, Fung WL, Koeleman CA, McDonnell LA, Verhoeven A, et al. N-glycosylation of colorectal cancer tissues: a liquid chromatography and mass spectrometry-based investigation. Mol Cell Proteomics. 2012;11:571-85.

14. Wang Q, Lasset C, Desseigne F, Saurin JC, Maugard C, Navarro C, et al. Prevalence of germline mutations of hMLH1, hMSH2, hPMS1, hPMS2, and hMSH6 genes in 75 French kindreds with nonpolyposis colorectal cancer. Hum Genet. 1999;105:79-85.

15. Aarnio M, Sankila R, Pukkala E, Salovaara R, Aaltonen LA, de la Chapelle A, et al. Cancer risk in mutation carriers of DNA-mismatch-repair genes. Int J Cancer. 1999:81:214-8.

16. Morohashi K. The ontogenesis of the steroidogenic tissues. Genes Cells. 1997;2:95-106

17. Raymond VM, Everett JN, Furtado LV, Gustafson SL, Jungbluth CR, Gruber SB, et al. Adrenocortical carcinoma is a lynch syndrome-associated cancer. J Clin Oncol. 2013;31:3012-8.

18. Committee on Practice Bulletins-Gynecology; Society of Gynecologic Oncology. ACOG practice bulletin No. 147: Lynch syndrome. Obstet Gynecol. 2014;124:1042-54.

\section{Submit your next manuscript to BioMed Central and we will help you at every step:}

- We accept pre-submission inquiries

- Our selector tool helps you to find the most relevant journal

- We provide round the clock customer support

- Convenient online submission

- Thorough peer review

- Inclusion in PubMed and all major indexing services

- Maximum visibility for your research

Submit your manuscript at www.biomedcentral.com/submit

) Biomed Central 